\title{
ADVANCEMENT IN ULTRASONIC VIBRATION AND MAGNETIC FIELD ASSISTED MICRO- EDM PROCESS: AN OVERVIEW
}

\author{
P. Mukhopadhyay \\ Research Scholar, Department of Production Engineering, \\ Jadavpur University, Kolkata, India \\ B. R. Sarkar \\ Assistant Professor, Department of Production Engineering, \\ Jadavpur University, Kolkata, India
}

\begin{abstract}
Micro-machining of components has been emerged as a peak demand in the world of micro-manufacturing. Micro-EDM is proved to be the most suitable for micro drilling purposes. It is very essential to fabricate micro holes as well as features with very high dimensional accuracy and precision. The major drawbacks in micro-EDM processes are the low metal removal, tool wear and surface roughness. Researchers have carried out several investigations to compensate the various machining problems in the microEDM process. So, there evolves a need for development of more sophisticated machining features in micro-EDM process combining with additional techniques. This paper presents a brief review on the latest advancement in ultrasonic vibration and magnetic field assisted techniques to improve machining efficiency and surface qualities of machined features in micro-EDM process. Latest industrial applications of microEDM have been presented.
\end{abstract}

Keywords: Micro-EDM, Ultrasonic vibration, Magnetic field

Cite this Article: P. Mukhopadhyay, B.R. Sarkar, Advancement in Ultrasonic Vibration and Magnetic Field Assisted Micro-EDM Process: An Overview, International Journal of Advanced Research in Engineering and Technology, 10 (2), 2019, pp 362-373.

http://iaeme.com/Home/issue/IJARET?Volume=10\&Issue $=2$

\section{INTRODUCTION}

Micro- EDM is an inevitable machining process in the field of micro-machining. It is a spark discharge machining method in which machining operations are accomplished by electrical discharges between tool and workpiece in an electrically insulated medium with the help of hydrocarbon oil, deionized water as dielectrics. Dissociation of ions causes a high temperature plasma channel in the gap resulted in restricted melting and evaporation of workpiece and electrode material. As a result of very high heat energy generated in the discharge region, wear occurs in the tool electrode. This directly affects the surface quality of machined products. In 
order to increase the metal removal rate as well as more improved surface features, researches have been performed on ultrasonic vibration to tool and workpiece materials in the micro-EDM process and magnetic field assisted techniques. The capability of machining complicated features with high dimensional accuracy in hard and complex to cut materials has made microEDM process as a vital and one of the most popular non-conventional machining processes. Micro holes with high aspect ratios and complex shapes can be fabricated with micro EDM process regardless of hardness. In comparison to conventional EDM, micro-EDM use lower discharge energies which results in smaller material removal per discharge and better accuracy. So, there evolves a need to preserve this attribute of micro-EDM process. Increasing demands for miniaturization and globalization of products led to the increase in the applications of microEDM. Introduction of dielectric vibration with $\mathrm{MoS}_{2}$ powder is a useful concept [9]. MicroEDM has been found to be suitable option for satisfying the increasing demand for smaller components of micro level in various industrial fields and for fabrication of micro components with good dimensional accuracy and repeatability $[12,17]$. It has been considered to be an outstanding machining process to produce smaller complex structures, which have wider scope of applications in aerospace industries. Machining performance of cryogenically treated tool electrodes and machining of sintered diamond have also been observed by researchers [19,20]. For micro-EDM, the most important applications are small precision cutting punches and dies, precision moulds, components for medical engineering, sensors and optics, watch making (gears and holes) or the production of small multi-component electrodes. Latest applications of micro-EDM in fabrication of micro holes in diesel injector nozzles, stainless steel shadow mask are very useful for future. One of the major disadvantages of utilizing micro-EDM is the low metal removal rate and high melting point for difficult to cut materials. Moreover, a common problem that generally can be seen in micro-EDM process is the poor flushing conditions in the discharge gap. Overall there is a need to have knowledge of latest modifications and developments in micro-EDM processes and parameters according to the requirements of machining industries for more advanced products with special micro features like 3D micro parts, multi batches micro parts, etc. Also, this study will directly benefit the researchers to carry out further analysis on advanced and hybridized micro machining process.

Therefore, this paper presents brief records of the new technologies developed to make an efficient micro-EDM process. Special attention has been given on vibration assisted microEDM and magnetic field assisted micro-EDM. Some recent applications like batch production of micro features and diesel injector nozzles have been cited down. Finally, a list of research works performed on various machining performance characteristics have been represented in tabular format and also percentage of research works carried out in the field of hybridised micro-EDM process have been represented graphically for the last 10 years.

\section{HISTORY AND JOURNEY OF MICRO-EDM PROCESS}

In the year 1770, English Physicist named Joseph Priestley conducted researches on the erosive effects of electrical discharges on various metals. After that in 1940, soviet researchers B.R. and N.I. Lazarenko developed a controlled process for erosion of metals by exploiting the destructive effects of electrical discharges in the form of sparks. In 1943, they developed a spark erosion machining process with spark generated between two electrical conductors (electrodes) immersed in dielectric fluid. In 1952, manufacturer Charmilles created the first machine using spark erosion machining process and was presented for the first time at the European Machine Tool Exhibition in 1955. Thereafter demand for miniature components and features led to the evolution of micro-EDM in 1968 by Kurafuzi and Masuzawa who had produced micro holes of 6 microns and 9 microns on cemented carbide alloy workpiece of 50 microns thickness. Consequently micro-EDM drilling also came to existence in 1969. The evolution of the wire 
EDM in the 1970s was due to powerful generators, new wire tool electrodes, better mechanical concepts improved machine intelligence, and better flushing. Since then, significant amount of research efforts has been focused on the development of micro-machining process. Requirement of miniatured components with good accuracy and great finishing features brought vibration assisted micro-EDM, micro-EDM grinding, magnetic field assisted microEDM process respectively into the scenario of micro-machining. Also sequential micro electro discharge machining combined with laser has been introduced in the year 2006. Finally simultaneous micro-EDM and micro-ECM come into the scenario of micro-machining in the year 2012. An initiative has been taken to represent the evolution of micro-EDM and its processes in the world of electro discharge machining as shown in fig.1.

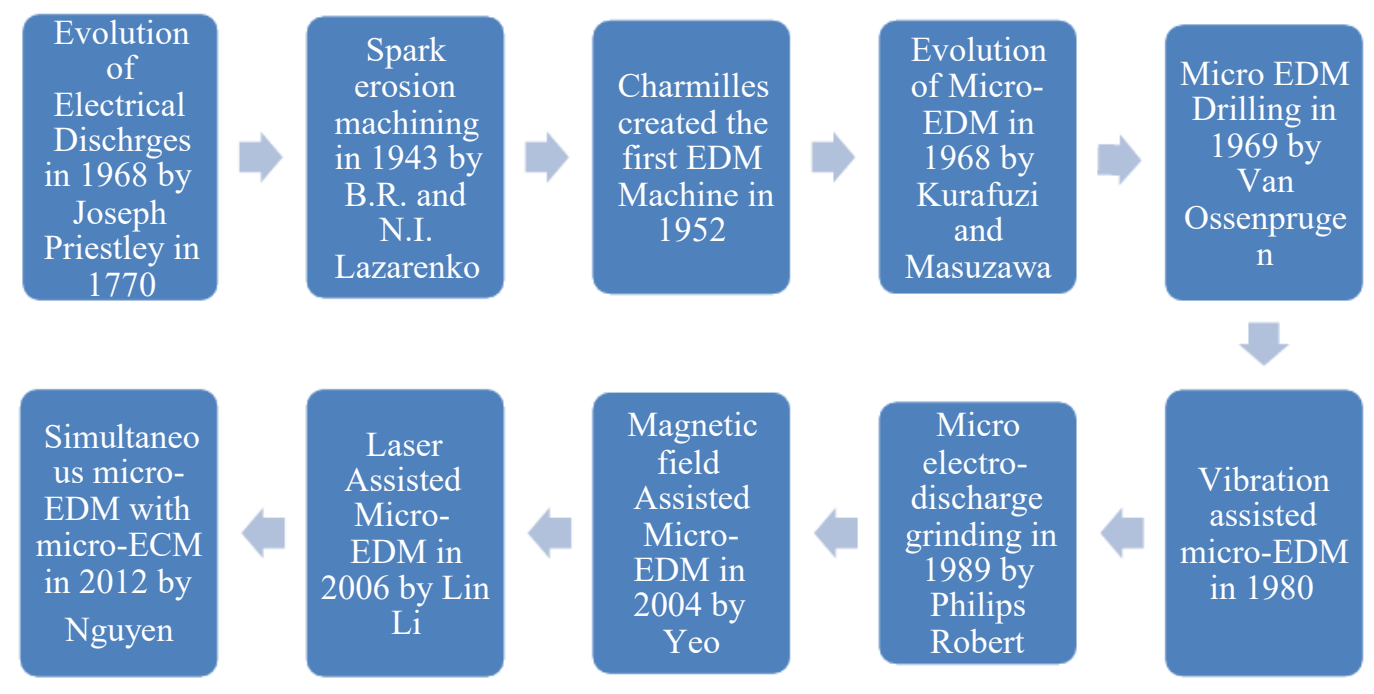

Figure 1 History of Evolution of Micro-EDM along with other processes

\section{DRAWBACKS OF MICRO-EDM}

There are many such drawbacks of micro-EDM process. One of the major disadvantages of using micro-EDM is the low metal removal rate and high melting temperature for difficult to cut materials. This may be due to the poor flushing conditions in the discharge gap causes tool wear in micro-EDM process, which can restrict the machining process at the middle of operation. Due to this, provision of the fabrication of multiple features with high dimensional accuracy is a problematic issue. Tool wear is caused by the thermal energy forming in the discharge gap. Abnormal discharges caused due to excessive heat between resolidified layers of workpiece and tool electrode resulted in dimensional inexactness and uneven surfaces. Researches are being carried out for use of non-conductive materials in micro-EDM process. The set up cost for micro-EDM process is very high due to repeated use of new tool electrode material caused by material erosion. On account of excessive tool wear due to indecent flushing and high peak current, the overall machining expenditure is quite high. There is a need for proper flushing arrangements in interelectrode gap between tool and workpiece during the interval of micro-EDMing.

\section{ADVANCEMENT IN ULTRASONIC VIBRATION ASSISTED MICRO-EDM}

A workpiece vibration assisted micro-EDM greatly influence the MRR. It helps in proper dielectric flushing and reduced the electric short circuiting due to the accumulation of debris particles in the machining zone. Ultrasonic vibration assisted micro-EDM process is mainly required for increasing the flushing pressure so that the debris particles are completely flushed 
out from the discharge gap and thus material removal rate gets increased. MRR is directly proportional to assisting vibration frequency. Machining efficiency increases to 6.5 times at the assisting vibration frequency of $5 \mathrm{KHz}$ and the amplitude of $2.7 \mu \mathrm{m}$, and the material removal rate is almost same as compared to dielectric vibration in micro-EDM [1]. Also, accumulation of debris particles at the machining zone and insufficient flushing give rise to reduced metal removal. The area of spark gap changes endlessly at low discharge energy upon application of vibration, which allows fresh dielectric to enter into the machining zone. In this way, the debris particles gets uninvolved completely and lead to the better machining efficiency [2]. Introduction of additives in dielectric fluid and using ultrasonic vibration considerably increased the material removal rate. As a replacement of using stirrer, ultrasonic vibration is applied to dielectric fluid in Micro-EDM. Vibration is induced to dielectric fluid by means of an ultrasonic bath. It is a significant factor in increasing material removal rate. Overall good surface quality and a very refined microstructure can be obtained with the use of ultrasonic dielectric vibration and micro $\mathrm{MoS}_{2}$ powder [3]. Recent achievements by the application of ultrasonic vibration to machining fluid in micro hole drilling are the reduction in tool wear ratio, lateral gap width. The machining time has been greatly reduced with ultrasonic vibration to machining fluid [4]. However tool electrode vibration assisted micro-EDM could be applied in the previous work to examine the effects on MRR and TWR. A method of micro-drilling of high aspect ratio micro-holes is established, in which the terrestrial movement of an electrode in addition with ultrasonic vibration provided an irregular distributed gap for the debris and bubbles helped to escape from the discharge zone easily. Micro hole with an aspect ratio of 29 has been drilled successfully by applying ultrasonic vibration and planetary movement of electrode in micro-EDM. This technique also contributes to the removal of debris and bubbles from the discharge zone easily [5]. Workpiece vibration at low frequency is suitable for smaller and deep micro holes of hard materials in respect of their dimensional accuracy. But excessive vibration beyond frequency limits could be harmful for machining process. It causes damage to tool electrode and also deformation in microstructures of workpiece. Tool wear could be reduced by vibration to tool electrode and machining performance can be enhanced with reduced machining time. An attempt to increase the depth of micro hole is implemented by inclined feeding of tool electrode in longitudinal direction [7]. Fig.2 shows the vibrating unit along with micro machining chamber have been designed and constructed. Vibrating unit consists of vibrating motors and an electrical circuit to run the motors in the normal power supply mode. The amplitude and frequency of vibrating unit are fixed. 


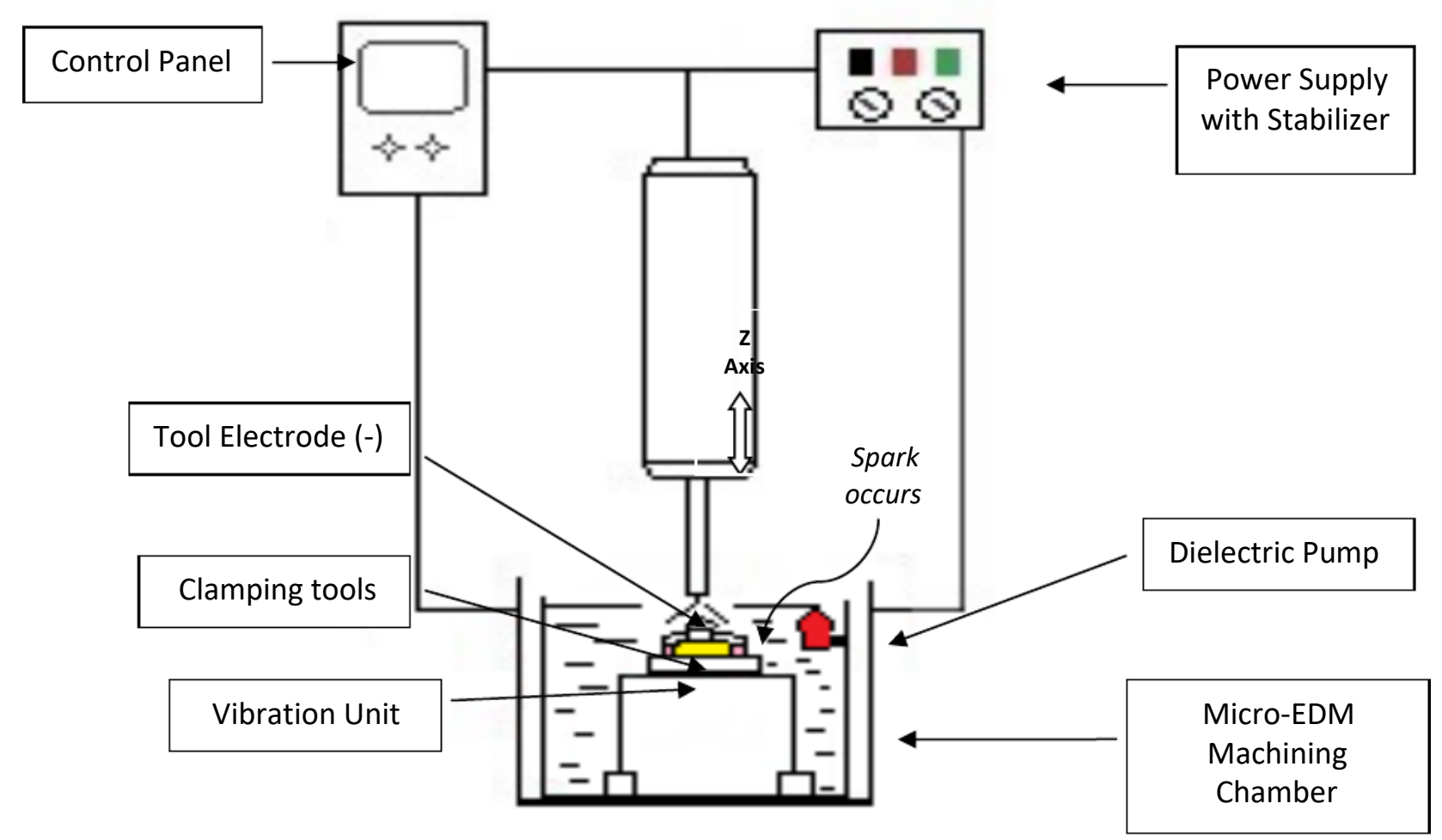

Figure 2 Ultrasonic Vibration Assisted Micro-EDM Process

The electrical circuit can convert $220 \mathrm{~V}$ AC to $4 \mathrm{~V}$ DC. Also, vibrational amplitude and frequency can be controlled by varying the output voltage. Experiments were done taking Polarity, Direction of Flushing, Gap Current and Pulse on Time as process parameters. MRR, TWR and Taperness were measured and it was found that Vibration employed to workpiece caused reduction in machining time for micro-EDMing. Also intensity of spark changes which depend upon the pulse on time and gap current. There is a visible abnormality in spark colour also with the changes in process parameters. For production of multiple micro holes, a micro punching machine is developed with application of vibration to the micro-EDM process for better machining performance characteristics [8]. Surface characteristics obtained without vibration have debris and craters attached to the micro formed features. Moreover the surface consists of HAZ and contained black spots or pin holes in different positions. On the other hand, the surface obtained using vibration assisted micro-EDM at same electrical settings was smoother and free of burr like recast layer. This is due to adequate flushing of debris particles caused from vibration of tool and workpiece in the machining region. There were no black spots on the surface obtained using vibration assisted micro-EDM [9]. Typical hole diameters ranging from 8 to $500 \mu \mathrm{m}$ and depth to diameter ratios of 20 or more have been achieved. At $500 \mathrm{~mA}$ peak current and $40 \mathrm{~V}$ dither voltage, micro-EDM coupled with high frequency dither grinding resulted in obtaining micro holes of precise shape and smooth surface after 6-8 min of lapping [10]. The surface obtained using vibration assisted micro-EDM is smoother and composed of smaller size craters at lower frequency workpiece vibration whereas micro-EDM combined with high frequency dither grinding (HFDG) yielded reduced surface roughness from 2.12 to $0.85 \mu \mathrm{m}$. The reason behind the small size of craters is lack of abnormal discharges caused due to proper flushing activities in the machining zone.

Dielectric vibration along with some abrasives is a economical and beneficial approach towards more better and optimized performance characteristics like increased material removal with good surface qualities. However tool vibration and workpiece vibration might not be a satisfactory approach for desired overall performance results. Better flushing of debris particles could be achieved by vibration assisted micro-EDM process thus reducing the chances of 
uneven spark discharges. Introduction of the through flushing tube electrodes and dielectric vibration with varying frequency in micro-EDM process could be a valuable movement towards improved surface quality of machined features.

\section{Advancement in Magnetic Field Assisted Micro-EDM}

There is a need for hybridisation of micro-EDM process with magnetic field force to increase the machining efficiency of micro electrical discharge machining process. Combination of micro-EDM and magnetic field is a major breakthrough in the field of micro machining. A novel process is developed and tested to improve material removal rate in magnetic field assisted micro-EDM for nonmagnetic materials. The workpiece electrodes were oriented to promote directionally in the current flowing through the workpiece, while an external magnetic field was applied in such a way as to produce a Lorrentz force in the melt pool. Single discharge actions were carried out on nonmagnetic Grade 5 titanium workpiece to investigate the mechanical effects of the Lorrentz force on material removal. MRR is increased upto nearly $50 \%$ and erosion efficiency increased by over $54 \%$ which is more than expected according to the works that have been performed till now [11]. This might be due to the reason that magnetic field generated in the discharge region helps in removal of debris from machining zone which further gives better flushing activities and thus abnormal discharges are stopped. Ultimately this contributes to the increased machining efficiency and MRR.

The slow response speed of servo system often leads to short circuit and arc discharge. To manage this limitation, a magnetic suspension spindle system was used to improve the response frequency. Using Incremental PID algorithm, the axial(Z) response frequency reaches $150 \mathrm{~Hz}$, the radial and axial position accuracy is achieved with $5 \mu \mathrm{m}$ and $2 \mu \mathrm{m}$. And the micro EDM is realized through the magnetic suspension spindle in $1.3 \mathrm{~mm}$ stroke [12]. Application of magnetic field to the process of micro-EDM improved the debris removal and hence the aspect ratio of micro-holes [19].

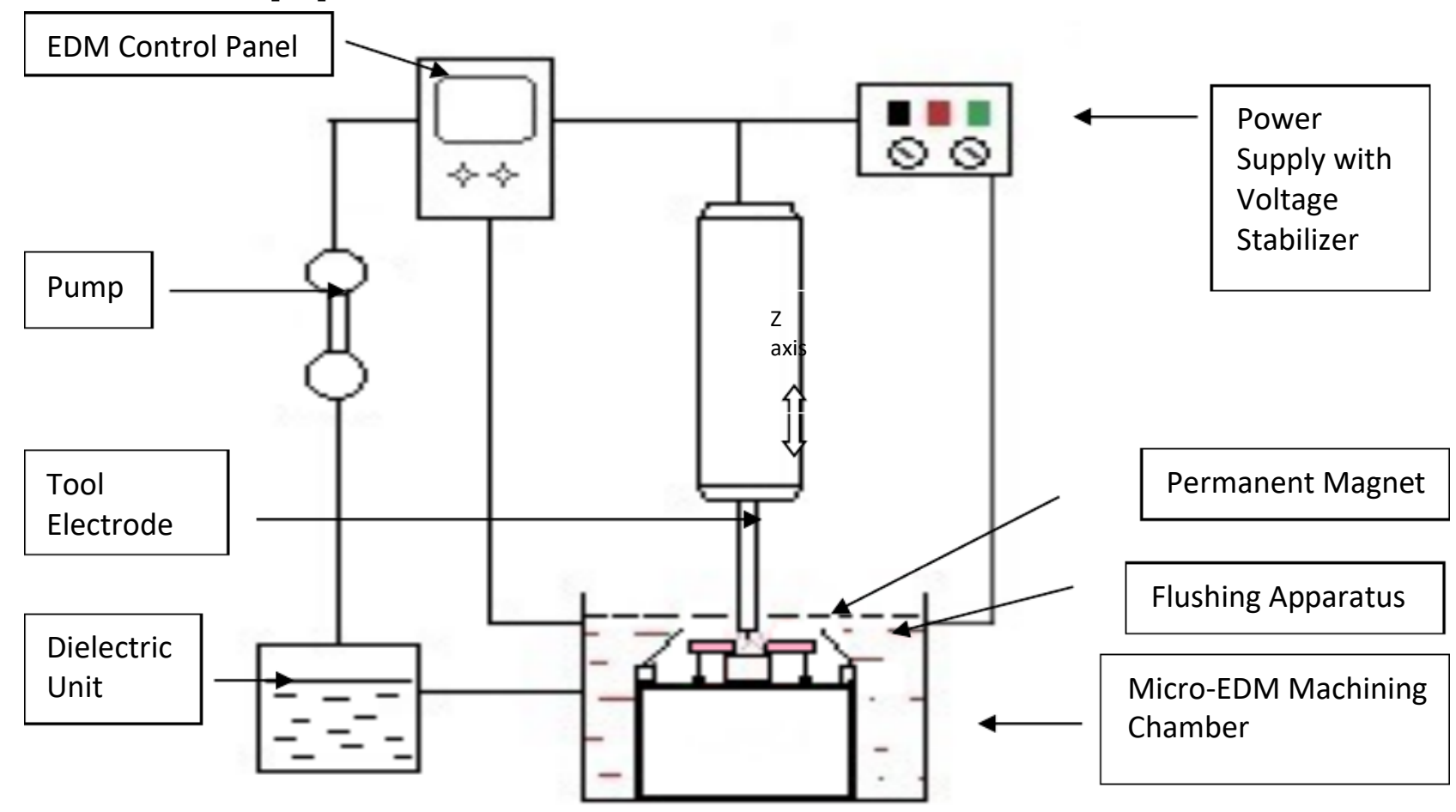

Figure 3 Magnetic Field Assisted Micro EDM Process 
Fig. 3 shows a schematic diagram magnetic field assisted micro-EDM process in which permanent magnets are used to generate the required magnetic lorrentz force. Sparking occurs in the plasma region surrounded by magnetic field which causes more removal of material from the workpiece.

Very few research works have been conducted using magnetic field assisted micro-EDM. Most of the research works are based on permanent magnets with fixed magnetic field force. Variable levels of magnetic fields need to be incorporated in further research works to analyze the effects on material removal rate and surface roughness more elaborately.

\section{INDUSTRIAL APPLICATIONS OF MICRO-EDM}

Development of a new feature by micro machining process without any industrial applications is just like a single point cutting tool without any machining applications in lathe. So, there is a provision of industrial applications of products, features fabricated by micro-EDM process. Promising applications are not only restricted to the machining of hard materials for micro moulds and cutting tools but also to the production of difficult to make structures such as fuel injection nozzles [14], spinneret holes for synthetic fibres, electronic and optical devices, micromechatronic actuator parts and micro tools for fabricating these devices [15,17]. Micro spherical styli for micro CMM's probing heads are fabricated by hybrid gluing and assembling process on micro EDM [18]. An array of 400 through holes of the identical sizes has been successfully fabricated on a stainless steel plate with at thickness of $30 \mu \mathrm{m}$ by upward batch micro-EDM process. Using the two effects of pumping and gravity, the upward batch microEDM facilitates the removal of debris and reduced the generation abnormal secondary discharges [23]. With micro-EDM drilling, reverse tapered micro holes (exit diameter of machined hole is larger than entry diameter) are produced which have a vast application in diesel fuel injector nozzles to improve emissions from diesel engines without the need for higher injection pressure or smaller diameter holes. A stainless steel shadow mask with high aspect ratio and high resolution has been developed using batch mode Micro-EDM. Spray holes of diesel injector nozzles made of $18 \mathrm{CrNi} 8$ material have been machined by micro-EDM process with greater accuracy and high machining efficiency [14]. A batch mode fabrication process of stainless steel shadow mask with high aspect ratio and high resolution for OTFTs is developed. This stainless steel shadow mask could be used as a patterning method to fabricate pentacene TFTs [15]. Kerosene is used as dielectric for batch production of stainless steel mass micro holes. But deionized water could have been used as dielectric for better results in respect of machining efficiency. A new piezoelectric ultrasonic servo control feed drive for electro discharge machining system industrial applications using piezoelectric ultrasonic technology is developed. The developed servo drive is validated successfully in EDM [20].

The research works carried out using ultrasonic vibration and magnetic field assisted microEDM process for the years 2006-2016 have been tabulated below.

\begin{tabular}{|c|l|l|l|c|l|l|}
\hline Serial no. & $\begin{array}{l}\text { Materials/ } \\
\text { Electrodes }\end{array}$ & $\begin{array}{c}\text { Machining } \\
\text { conditions/ } \\
\text { process }\end{array}$ & Research works performed & Year & Reported by & \multicolumn{1}{|c|}{ Remarks } \\
\hline 1. & $\begin{array}{l}\text { Tungsten } \\
\text { carbide of } \phi \\
500 \mathrm{~mm} \\
\text { (Tool), high- } \\
\text { nickel alloy } \\
\text { (workpiece) }\end{array}$ & $\begin{array}{l}\text { Micro-EDM } \\
\text { combined with } \\
\text { HFDG, Dither } \\
\text { input voltage-40V, } \\
\text { Dither frequency- }\end{array}$ & $\begin{array}{l}\text { High Frequency Dither Grinding } \\
\text { (HFDG) has been applied to } \\
\text { micro-EDM. }\end{array}$ & 2006 & $\begin{array}{l}\text { Liu H. S., Yan } \\
\text { B. H., Chen } \\
\text { C.L., Huang } \\
\text { F.Y., }\end{array}$ & $\begin{array}{l}\text { Good surface quality } \\
\text { has been observed. For } \\
\text { high peak current, the } \\
\text { duration of high } \\
\text { frequency dither } \\
\text { grinding may be } \\
\text { increased to eliminate } \\
\text { the discharge craters. }\end{array}$ \\
\end{tabular}




\begin{tabular}{|c|c|c|c|c|c|c|}
\hline 2. & $\begin{array}{l}\text { High nickel } \\
\text { alloy (Hymu } \\
\text { 80) as } \\
\text { workpiece and } \\
\text { Tungsten } \\
\text { carbide as tool } \\
\text { electrode }\end{array}$ & $\begin{array}{l}\text { Micro-EDM } \\
\text { process with } \\
\text { WEDG, discharge } \\
\text { current- } 100 \mathrm{~mA}, \\
\text { pulse duration- } 4 \mu \mathrm{s} \text {, } \\
\text { open voltage- } \\
250 \mathrm{~V} \text {, gap voltage- } \\
57 \mathrm{~V}\end{array}$ & $\begin{array}{l}\text { A novel process has been } \\
\text { implemented using micro-EDM } \\
\text { combined with ultrasonic vibration } \\
\text { by a helical micro-tool electrode to } \\
\text { drill micro holes of precise shape } \\
\text { and smooth surface }\end{array}$ & 2006 & $\begin{array}{l}\text { Hung J.C., Lin } \\
\text { J.K., Yan B.H., } \\
\text { Liu H.S., Ho } \\
\text { P.H., }\end{array}$ & $\begin{array}{l}\text { Good surface quality } \\
\text { and less taper of the } \\
\text { hole wall has been } \\
\text { obtained. }\end{array}$ \\
\hline 3. & $\begin{array}{l}\text { Red copper } \\
\text { plate } \\
\text { (workpiece), } \\
\text { Tungsten (tool } \\
\text { electrode) }\end{array}$ & $\begin{array}{l}\text { Micro-EDM } \\
\text { process, open } \\
\text { voltage- } 110 \mathrm{~V}, \\
\text { peak current- } 1.25 \\
\text { A, scanning } \\
\text { velocity- } 0.5 \mathrm{~mm} / \mathrm{s}\end{array}$ & $\begin{array}{l}\text { Several typical 3D micro } \\
\text { structures have been successfully } \\
\text { machined by the method of } \\
\text { workpiece vibration assisted servo } \\
\text { scanning 3D micro-EDM. }\end{array}$ & 2008 & $\begin{array}{l}\text { Hao T., Yang } \\
\text { W., Yong L., }\end{array}$ & $\begin{array}{l}\text { The Machining } \\
\text { efficiency increased to } \\
6.5 \text { times at the } \\
\text { assisting vibration } \\
\text { frequency of } 5 \mathrm{kHz} \text { and } \\
\text { amplitude of } 2.7 \mu \mathrm{m} .\end{array}$ \\
\hline 4. & $\begin{array}{l}\text { Stainless steel } \\
\text { (Workpiece), } \\
\text { Tungsten } \\
\text { (Tool), } \\
\text { Deionized } \\
\text { water } \\
\text { (dielectric) }\end{array}$ & $\begin{array}{l}\text { Micro-EDM } \\
\text { drilling, open } \\
\text { circuit voltage- } 80 \\
\text { V, capacitance- } \\
\text { 1000pF, Frequency } \\
\text { of Ultrasonic } \\
\text { vibration- } 49 \mathrm{KHz}\end{array}$ & $\begin{array}{l}\text { Drilling of micro holes have been } \\
\text { done by planetary movement of } \\
\text { electrode and ultrasonic vibration } \\
\text { in micro-EDM process. This new } \\
\text { method provided an unevenly } \\
\text { distributed gap for debris and } \\
\text { bubbles to escape from the } \\
\text { discharge zone easily. Micro-holes } \\
\text { with aspect ratio of } 29 \text { have been } \\
\text { drilled. }\end{array}$ & 2009 & $\begin{array}{l}\text { Yu Z.Y., } \\
\text { Zhang Y., Li } \\
\text { J., Luan J., } \\
\text { Zhao F., Guo } \\
\text { D., }\end{array}$ & $\begin{array}{l}\text { Electromagnetic force } \\
\text { and pressure of } \\
\text { bubbles generated by } \\
\text { evaporation and } \\
\text { dissociation of the } \\
\text { dielectric liquid caused } \\
\text { the long and thin } \\
\text { electrode to bend. } \\
\text { Movement of such } \\
\text { electrode tip was } \\
\text { complex. }\end{array}$ \\
\hline 5. & $\begin{array}{l}\text { Copper, } \\
\text { Copper- } \\
\text { tungsten, } \\
\text { silver-tungsten } \\
\text { as workpiece } \\
\text { materials, } \\
\text { Brass as tool } \\
\text { electrode, } \\
\text { kerosene as } \\
\text { dielectric with } \\
\mathrm{MoS}_{2} \text { powder }\end{array}$ & $\begin{array}{l}\text { Micro-EDM } \\
\text { process, vibration } \\
\text { frequency- } 43 \\
\mathrm{KHz} \text {, charge } \\
\text { voltage- } 110 \mathrm{~V} \text {, feed } \\
\text { rate- } 5 \mu \mathrm{m} / \mathrm{s} \\
\end{array}$ & $\begin{array}{l}\text { Effects of micro } \mathrm{MoS}_{2} \text { powder and } \\
\text { ultrasonic vibration of dielectric } \\
\text { fluid has been investigated in } \\
\text { micro-EDM process. It resulted in } \\
\text { increase of material removal rate } \\
\text { and improves surface quality by } \\
\text { providing a flat surface free of } \\
\text { black carbon spots. }\end{array}$ & 2009 & $\begin{array}{l}\text { Prihandana } \\
\text { G.S., } \\
\text { Mahardika M., } \\
\text { Hamdi M., } \\
\text { Wong Y.S., } \\
\text { Mitsui K., }\end{array}$ & $\begin{array}{l}\text { The experiments need } \\
\text { to be done with } \\
\text { variable frequency and } \\
\text { amplitude of dielectric } \\
\text { vibration for more } \\
\text { detailed analysis of } \\
\text { performance } \\
\text { characteristics. }\end{array}$ \\
\hline 6. & $\begin{array}{l}\text { ANSI } 1045 \\
\text { (workpiece), } \\
\text { red copper } \\
\text { (tool electrode) }\end{array}$ & $\begin{array}{l}\text { Micro-EDM } \\
\text { process, RC pulse } \\
\text { power supply, Gap } \\
\text { voltage- } 220 \mathrm{~V}, \\
\text { peak current- } 0.8 \\
\text { A, capacitance- } \\
220 \mathrm{pF}\end{array}$ & $\begin{array}{l}\text { Empirical mode decomposition } \\
\text { method has been adopted for the } \\
\text { prediction of discharge states } \\
\text { obtained by multisensory data } \\
\text { fusion and fuzzy logic in micro- } \\
\text { EDM. }\end{array}$ & 2010 & $\begin{array}{l}\text { Jia Z., Zhang } \\
\text { L., Wang F., } \\
\text { Liu W., }\end{array}$ & $\begin{array}{l}\text { This new method } \\
\text { provided a good basis } \\
\text { to enhance the stability } \\
\text { of the control system. } \\
\text { But research is needed } \\
\text { to enhance the } \\
\text { accuracy of IMF high } \\
\text { frequency component. }\end{array}$ \\
\hline 7. & \begin{tabular}{|l} 
Grade 5 \\
Titanium \\
(workpiece), \\
Tungsten wire \\
of $100 \mu \mathrm{m}$ (tool \\
electrode)
\end{tabular} & $\begin{array}{l}\text { Micro-EDM } \\
\text { process, open gap } \\
\text { voltage- } 100 \mathrm{~V}, \\
\text { discharge power- } \\
100 \text { to } 150 \mathrm{~W}\end{array}$ & $\begin{array}{l}\text { A novel process has been } \\
\text { developed and tested to improve } \\
\text { material removal rate in magnetic } \\
\text { field assisted } \mu \text {-EDM for } \\
\text { nonmagnetic materials. By the } \\
\text { orientation of Lorrentz force to act } \\
\text { in a direction, MRR was shown to } \\
\text { increase by upto } 50 \% \text { and erosion } \\
\text { efficiency by over } 54 \% \text {. }\end{array}$ & 2011 & $\begin{array}{l}\text { Heinz K., } \\
\text { Kapoor S.G., } \\
\text { Devor R.E., } \\
\text { Surla V., }\end{array}$ & $\begin{array}{l}\text { Effects of variable } \\
\text { electromagnetic field } \\
\text { strength with more } \\
\text { than unity need to be } \\
\text { analyzed on response } \\
\text { parameters of micro- } \\
\text { EDM process. }\end{array}$ \\
\hline 8. & $\begin{array}{l}\text { WC-Co as tool } \\
\text { and workpiece } \\
\text { material, } \\
\text { Deionized } \\
\text { water as } \\
\text { dielectric fluid }\end{array}$ & $\begin{array}{l}\text { Micro-EDM } \\
\text { Process, Positive } \\
\text { voltage- } 80 \mathrm{~V}, \\
\text { Positive duration- } \\
0.2 \mu \mathrm{s}, \\
\text { Capacitance- } \\
390 \mathrm{pF}\end{array}$ & $\begin{array}{l}\text { Investigation on characteristics for } \\
\text { prevention of electrolytic } \\
\text { corrosion during micro-EDM } \\
\text { using deionized water and high } \\
\text { frequency bipolar pulse }\end{array}$ & 2012 & $\begin{array}{l}\text { Chung D.K., } \\
\text { Shin H.S., Chu } \\
\text { C.N., }\end{array}$ & $\begin{array}{l}\text { When average gap } \\
\text { voltage was negative, } \\
\text { tool was heavily } \\
\text { corroded resulted in } \\
\text { imbalanced machining } \\
\text { thus finally increases } \\
\text { the machining time. }\end{array}$ \\
\hline 9. & $\begin{array}{l}\text { WC of grade } \\
\text { MG18 } \\
\text { (Workpiece), } \\
\text { pure tungsten } \\
\text { (tool) of } \phi \\
200 \mu \mathrm{m} \\
\end{array}$ & $\begin{array}{l}\text { Micro-EDM } \\
\text { drilling, Vibration } \\
\text { frequency- } 750 \mathrm{~Hz} \text {, } \\
\text { Voltage- } 100 \mathrm{~V}, \\
\text { capacitance- } 1000- \\
10,000 \mathrm{pF}\end{array}$ & $\begin{array}{l}\text { Evaluation of effectiveness of low } \\
\text { frequency workpiece vibration } \\
\text { during deep hole drilling by micro- } \\
\text { EDM. Vibration frequency of } 750 \\
\text { Hz and amplitude of } 1.5 \mu \mathrm{m} \text { have } \\
\text { been found to provide improved }\end{array}$ & 2012 & $\begin{array}{l}\text { Jahan M.P., } \\
\text { Wong Y.S., } \\
\text { Rahman M., }\end{array}$ & $\begin{array}{l}\text { Vibration with } \mathrm{K}_{\mathrm{V}}<1 \text { is } \\
\text { found to be inefficient } \\
\text { for machining of } \\
\text { aspect ratio } 7.5 \text { and } \\
\text { higher micro holes in } \\
\text { tungsten carbide. }\end{array}$ \\
\hline
\end{tabular}




\begin{tabular}{|c|c|c|c|c|c|c|}
\hline & & & $\begin{array}{l}\text { performance for the developed } \\
\text { vibration device. }\end{array}$ & & & \\
\hline 10. & $\begin{array}{l}\text { SUS } 304 \\
\text { (Workpiece), } \\
\text { Tungsten (tool) } \\
\text { of } \phi 40 \mu \mathrm{m}, \\
\text { CASTY-LUBE } \\
\text { EDS } \\
\text { (Dielectric } \\
\text { fluid) }\end{array}$ & $\begin{array}{l}\text { Micro-EDM and } \\
\text { WEDG, RC } \\
\text { circuit, ultrasonic } \\
\text { frequency-43 } \pm 1.5 \\
\mathrm{KHz}\end{array}$ & $\begin{array}{l}\text { Effects of application of ultrasonic } \\
\text { vibration to machining fluid under } \\
\text { ultra small discharge energy has } \\
\text { been investigated for deep micro } \\
\text { hole drilling in micro-EDM } \\
\text { process }\end{array}$ & 2013 & $\begin{array}{l}\text { Ichikawa T., } \\
\text { Natsu W., }\end{array}$ & $\begin{array}{l}\text { Large amplitude of } \\
\text { tool electrode vibration } \\
\text { increases hole diameter } \\
\text { and thus overcut and } \\
\text { taperness are } \\
\text { increased. }\end{array}$ \\
\hline 11. & $\begin{array}{l}\text { AISI } 304 \\
\text { (Workpiece), } \\
6061 \\
\text { Aluminium } \\
\text { Alloy } \\
\text { (Workpiece), } \\
\text { Tungsten } \\
\text { Carbide } \\
\text { lectrode of } \\
200 \mu \mathrm{m} \\
\text { diameter }\end{array}$ & $\begin{array}{l}\text { Micro-EDM } \\
\text { drilling with } \\
\text { inclined feed of } \\
\text { electrode and } \\
\text { vibration of } \\
\text { electrode in } \\
\text { longitudinal } \\
\text { direction }\end{array}$ & $\begin{array}{l}\text { The depth of hole is increased } \\
\text { when the aluminium alloy } 6061 \text { is } \\
\text { drilled by a } 200 \mu \mathrm{m} \text { in diameter } \\
\text { electrode using a } 10 \text { degree } \\
\text { downward electrode feeding with } \\
\text { axial vibration having } 250 \mathrm{~Hz} \text { as } \\
\text { frequency and } 5 \mu \mathrm{m} \text { as amplitude } \\
\text { in micro-EDM process }\end{array}$ & 2016 & $\begin{array}{l}\text { Kumar J.S.U., } \\
\text { Prasad } \\
\text { CLVRSV, Rao } \\
\text { K.S., }\end{array}$ & $\begin{array}{l}\text { Maximum aspect ratio } \\
\text { obtained is } 24 \text { and } 26 \\
\text { for } \mathrm{Al} 6061 \text { and AISI } \\
304 \text { respectively. }\end{array}$ \\
\hline
\end{tabular}

Micro ball ended spherical stylus tips for micro coordinate measuring machine's (CMM's) tactile probing heads is one of the most prominent application of micro-EDM process in which roundness of the largest profile micro glass ball ended styli with a $0.07 \mathrm{~mm}$ diameter is as small as $0.613 \mu \mathrm{m}$ compared to micro die fabrication by micro-EDM in which micro holes of 300 , 150 and $100 \mu \mathrm{m}$ in diameter is performed with high dimensional accuracy. Diesel injector nozzles are one of the vital products fabricated by micro-EDM process.

\section{SUMMARY}

Micro-EDM is proved to be one of the most challenging micro machining process for machining of conductive materials like Nickel and Titanium alloy. Latest methods to improve flushing conditions and MRR have been discussed. Different techniques to improve machining performance like application of dielectric vibration with suspended micro $\mathrm{MoS}_{2}$ powder in micro-EDM process have been presented. Specially, the production of batch micro holes, diesel injector nozzles are some of the latest upcoming challenges in the field of micro machining. Magnetic field assisted micro-EDM drilling and vibration assisted micro-EDM are the most successful hybridization process in the field of micro-EDMing. However more research works could be expected in the field of magnetic field assisted micro-EDM processes with varying magnetic field intensities. Also instead of using additives in micro-EDMing of materials, hybridization of process might be helpful for quick and efficient super finishing features in micro machining processes.

Based on this study, it could be understood that MRR and surface roughness are the most vital and valuable response parameters in micro-EDM process. They are directly related to machining efficiency. So, there should have efficient and reliable techniques like ultrasonic vibration, magnetic field, etc. to obtain the desired and optimized values these response parameters.

Based on the recent research works done in the field of Micro-EDM, a pie chart has been drawn in fig.4 representing the percentage of hybridized and external force assisted MicroEDM for the duration of year between 2006-2018. 
Advancement in Ultrasonic Vibration and Magnetic Field Assisted Micro-EDM Process:

An Overview

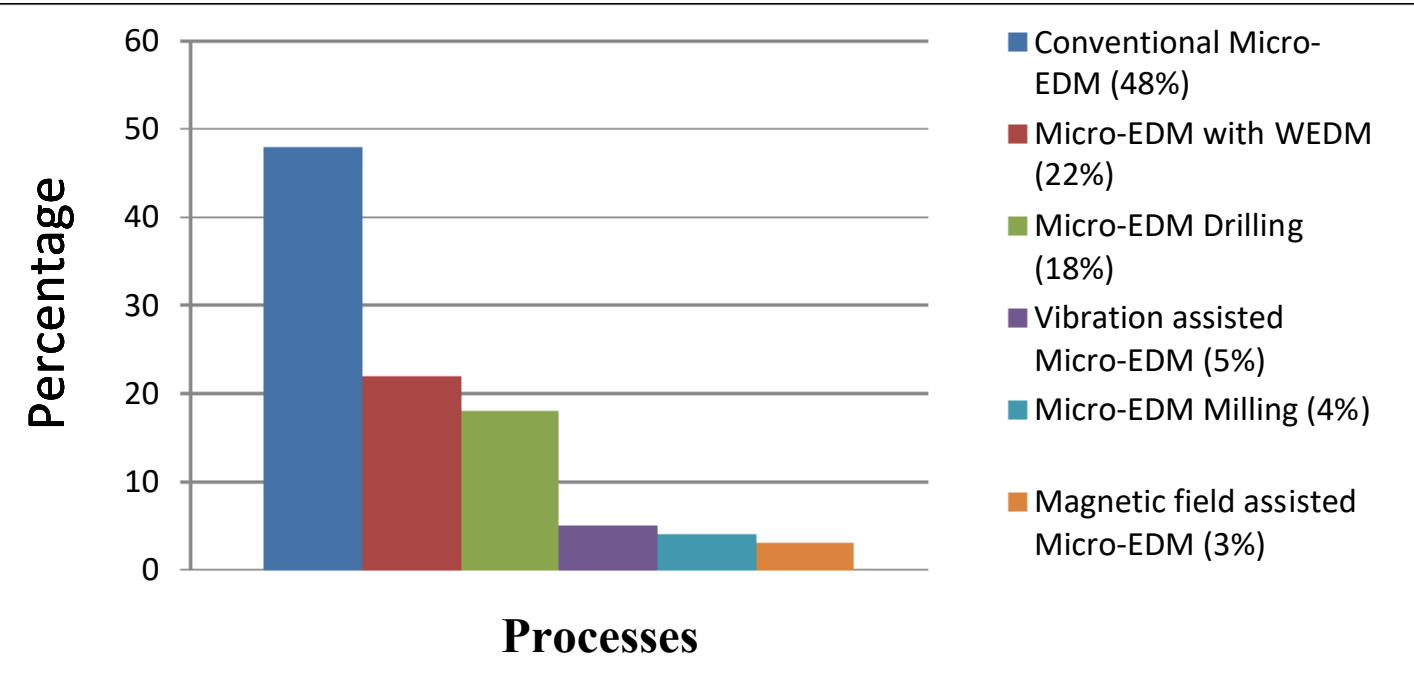

Figure 4. Different processes hybridised with micro-EDM

\section{FUTURE SCOPE OF WORK}

- Fundamentals of micro-EDM can be utilized in the wide variety of applications of computational fluid dynamics.

- Knowledge of mechanism of material removal will be helpful for thorough understanding of ion plasma dissociation theory.

- Ferromagnetic tools and ceramic materials coated with conductive layer are challenging machineable materials in the recent fields of micro/nano electrical discharge machining.

- Still, there is a need for more research works in dielectric vibration and variable magnetic field force assisted micro-EDM process to obtain optimized results.

\section{ACKNOWLEDGEMENT}

The authors wish to acknowledge the support provided by CAS Ph-IV Programme, Production Engineering Department, Jadavpur University, Kolkata (INDIA).

\section{REFERENCES}

[1] Hao T, Yang W, Yong Li, Vibration assisted servo scanning 3D micro EDM, Journal of Micromechanics and Microengineering, Vol.18, No.2. (2008)

[2] Jahan M.P., Wong Y.S., Rahman M, Evaluation of the effectiveness of low frequency workpiece vibration in deep-hole micro-EDM drilling of tungsten carbide, Journal of Manufacturing Processes, Vol.14, Issue 3, (2012) pp.343-359.

[3] Prihandana Gunawan Setia, Mahardika Muslim, Hamdi M, Wong Y.S., Mitsui Kimiyuki, Effect of micro-powder suspension and ultrasonic vibration of dielectric fluid in microEDM processes-Taguchi approach, International Journal of Machine Tools \& Manufacture, (2009) 49:1035-1041.

[4] Ichikawa T., Natsu W., Realization of micro-EDM under ultra-small discharge energy by applying ultrasonic vibration to machining fluid, The Seventeenth CIRP Conference on Electro Physical and Chemical Machining (ISEM), (2013) 6:327-332.

[5] Yu Z.Y., Zhang Y., Li J., Luan J., Zhao F., Guo D., High aspect ratio micro hole drilling aided with ultrasonic vibration and planetary movement of electrode by micro-EDM, CIRP Annuals- Manufacturing Technology, (2009) 58:213-216. 
[6] Kumar J.S.U., Prasad CLVRSV, Rao K.S., Simulation Studies of Impact of Electrode Geometry on Thermal Profiles in Micro EDM by using CFX tools, International Journal of Mechanical Engineering and Technology, Vol.7, Issue 4, July-Aug 2016, pp.196-204.

[7] Liao Y.S., Liang H.W., , Study of Vibration Assisted Inclined Feed Micro-EDM Drilling, $18^{\text {th }}$ CIRP Conference on Electro Physical and Chemical Machining, Procedia CIRP 42, (2016) 552-516.

[8] ChernGwo-Lianq, Wu Ying-JengEngin, Liu Shun-Feng, Development of a micro-punching machine and study on the influence of vibration machining in micro-EDM, Journal of Materials Processing Technology, 180, (2006) pp. 102-109.

[9] Jahan M P, Saleh T, Rahman M, Wong Y S, Development, modeling and experimental investigation of low Frequency workpiece vibration-assisted Micro-EDM of tungsten carbide, Journal of Manufacturing Science and Engineering, vol.132. (2010)

[10] Liu H S, Yan B H, Chen C L, Huang F Y, Application of micro-EDM combined with highfrequency dither grinding to micro-hole machining, International Journal of Machine Tools\& Manufacture, (2006) 46:80-87.

[11] Heinz K, Kapoor S G, Devor R E, Surla V, An investigation of magnetic-field-assisted material removal in micro-EDM for nonmagnetic materials, Journal of Manufacturing Science and Engineering, vol.133. (2011)

[12] Guo Y., Ling Z., A magnetic susupension spindle system for micro-EDM, 18th CIRP Conference on Electro Physical and Chemical Machining (ISEM XVIII), vol.42, (2016) pp543-546.

[13] Kibria G, Sarkar B R, Pradhan B B, Bhattacharyya B, Comparative study of different dielectrics for micro-EDM performance during microhole machining of Ti-6Al-4V alloy, International Journal of Advanced Manufacturing Technology, (2010) 48:557-570.

[14] Hao T, Yong Li, Long Z, Baoquan Li, Mechanism design and process control of micro EDM for drilling spray holes of diesel injector nozzles, Journal of Precision Engineering, (2013) 37:213-221.

[15] Yi S M, Park M S, Lee Y S, Chu C N, Fabrication of a stainless-steel shadow mask using batch mode micro-EDM, Journal of Microsystem Technology, (2008) 14:411-417.

[16] Chung D K, Shin H S, Chu C N, Modeling and experimental investigation for electrolytic corrosion prevention in high frequency micro EDM using deionized water, Journal of Microsystem Technology, (2012) 18:703-712.

[17] Xu J, Guo B, Shan D, Wang Z, Li M, Fei X, Micro-punching process of stainless steel foil with micro-die fabricated by micro-EDM, Journal of Microsystem Technology, Vol.20, Issue 1, (2013) pp. 83-89.

[18] Sheu D Y, Cheng C C, Assembling ball-ended styli for CMM's tactile probing heads on micro EDM, International Journal of Advanced Manufacturing Technology, Vol.65, Issue 1-4, (2012) pp. 485-492.

[19] Yeo S H, Murali M, Cheah H T, Magnetic field assisted micro electro-discharge machining, Journal of Micromechanics and Microengineering, (2004) 14:1526-1529.

[20] Shafiq M, Abdalla H S, Fransson P, A piezoelectric servo feed drive for electro discharge machining system industrial applications using linear ultrasonic motor, Journal of Manufacturing Science and Engineering, vol.135. (2013)

[21] PradhanB B, Masanta M, Sarkar B R, Bhattacharyya B, Investigation of electro-discharge micro-machining of titanium super alloy, International Journal of Advanced Manufacturing Technology, (2012) 41, 1094-1106.

[22] Hung J C, Lin J K, Yan B H, Liu H S, Ho P H, using a helical micro-tool in micro-EDM combined with ultrasonic vibration for micro-hole machining, Journal of Micromechanics and Microengineering, (2006) 16:2705-2713.

[23] Chen S T, Fabrication of high-density micro holes by upward batch micro EDM, Journal of Micromechanics andMicroengineering, Vol.18, No. 8. (2008) 
Advancement in Ultrasonic Vibration and Magnetic Field Assisted Micro-EDM Process:

An Overview

[24] Zhang L., Tong H., Li Y., Precision machining of micro tool electrodes in micro EDM for drilling array micro holes, Journal of Precision Engineering, vol.39, (2015) pp 100-106.

[25] Li L., Diver C., Atkinson J., Giedl-Wagner R., Helml H.J., Sequential laser and EDM microdrilling for next generation fuel injector nozzle manufacture, Annuals of the CIRP, vol.55/1. (2006)

[26] Kumar S., Grover S., Walia R.S, Optimisation strategies in ultrasonic vibration assisted electrical discharge machining: a review, International Journal of Precision Technology, vol.7, (2017) pp.51-84.

[27] Govindam P., Gupta A., Joshi S.S., Malshe A., Rajurkar K.P., Single spark analysis of removal phenomenon in magnetic field assisted dry EDM , Journal of Materials Processing Technology, vol.213, (2013) pp.1048-1058.

[28] Unune D.R., Nirala C.K., Mali H.S., Accuracy and quality of micro holes in vibration assisted micro electro discharge drilling of Inconel 718, Measurement, vol.135, (2019), Pp. 424-437.

[29] Goyal S., Gupta V., Sharma S., Sharma H., Effect of EDM Process Parameters on Material Removal Rate, Surface Roughness \& Tool Wear Rate, International Journal of Mechanical Engineering and Technology, Vol.9, Issue 4, April 2018, (2018) pp.231-239.

[30] Abbas M.A., Lajis M.A.B., Ridha G.S.A., A New Methodology for Predicting Quantity of Agglomeration Between Electrodes in PMEDM Environment, International Journal of Mechanical Engineering and Technology, Vol.10, Issue 2, February 2019, (2019) pp.14611479.

[31] Dr.T. Vijaya Babu, S. Venukumar, Surya Prakash and N Santhisree, Optimization of Wedm Process Parameters on Al 7075 By Using Taguchi Technique And Response Surface Methodology (Rsm), International Journal of Mechanical Engineering and Technology 8(8), 2017, pp. 941-950.

[32] Prabhjot Balraj Singh, Mahipal Singh and Gurpreet Singh Phull Parametric Analysis of Cryogenic Treatment on En31 Material Using EDM Process. International Journal of Mechanical Engineering and Technology, 8(7), 2017, pp. 1615-1626.

[33] G. R. Sanjay Krishna, N. Naveen Kumar, V V S D S Aditya Koka, Padala Narendra and P. Chaitanya, Parametric Analysis of Wire EDM Process Variables Using Grey Analysis, International Journal of Mechanical Engineering and Technology, 9(4), 2018, pp. 248-257.

[34] R. Rajesh, M. Dev Anand and K.N. Benny. Prediction of EDM Process Parameters for AISI 1020 Steel Using RSM, GRA and ANN. International Journal of Mechanical Engineering and Technology, 8(5), 2017, pp. 924-940.

[35] Manpreet Singh, Amandeep Singh Bansal and Sanjeev Kumar, The Effect of Different Wire Electrodes on The MRR of MS Workpiece Using Wedm Process, International Journal of Mechanical Engineering and Technology (IJMET), Volume 5, Issue 5, May (2014), pp. 180-188

[36] S V Subrahmanyam and M. M. M. Sarcar, Wedm Process Modeling with Data Mining Techniques, International Journal of Advanced Research in Engineering and Technology (IJARET), Volume 4, Issue 7, November - December 2013, pp. 161-169 